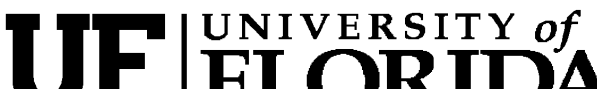 FLORIDA \\ IFAS Extension
}

\section{Variable Rate Technology for Florida Citrus ${ }^{1}$}

\author{
Reza Ehsani, Arnold Schumann, and Masoud Salyani
}

Precision agriculture technology is fast emerging as an aid to the farming community by improving production efficiency, reducing environmental pollution from agrochemicals, and increasing profits. Variable rate technology (VRT) is an important site-specific management component of precision agriculture which provides economic benefits to growers while reducing the application of agrochemicals, including fertilizer, and irrigation water.

Conventional uniform grove management disregards the needs of individual trees based on their size, age, or the variability of soil properties. Variable rate application of grove inputs is one of the useful ways to reduce production costs, increase profitability of citrus production, and have a positive environmental impact. Many studies of site-specific management with row crops such as variable rate nitrogen fertilization of corn have failed to demonstrate repeatable economic benefits. Fortunately, that is not the case in Florida citrus, where consistent economic benefits and early payback of VRT equipment are possible if there is enough exploitable variability in the grove.
Variable rate application can be geographic information system (GIS) map-based, "on-the-go" sensor-based, or a combination of map and sensor-based. GIS map-based variable rate application is popular for row crops where the application amounts and rates are predetermined, for example the application amount may be decided for each section of the field based on soil fertility tests. Sensor-based and combination variable rate methods are more suitable in tree crops like citrus because there are sensors available that can quantify the fertilizer need of each individual tree by measuring tree height or size. Various sensors have been used to measure the height or the canopy volume of trees to apply the right amount of fertilizer or chemicals.

\section{Components of VRT}

Figure 1 shows the main components of a typical VRT system. In a map-based VRT system, the VRT controller uses a predefined application map (prescription map) to change the application rate. In a sensor-based VRT system, the controller uses the input from the sensor to change the application rate on-the-go. Both the map-based and sensor-based VRT applicators need some type of volume or mass

1. This document is AE444, one of a series of the Agricultural and Biological Engineering Department, Florida Cooperative Extension Service, Institute of Food and Agricultural Sciences, University of Florida. Original publication date January 2009. Visit the EDIS Web Site at http://edis.ifas.ufl.edu.

2. Reza Ehsani, assistant professor, Department of Agricultural and Biological Engineering, Citrus Research and Education Center (REC)-Lake Alfred; Arnold Schumann, associate professor, Department of Soil and Water Science; Masoud Salyani, professor, Department of Agricultural and Biological Engineering, Citrus REC-Lake Alfred; Florida Cooperative Extension Service, Institute of Food and Agricultural Sciences, University of Florida, Gainesville, FL 32611.

The Institute of Food and Agricultural Sciences (IFAS) is an Equal Opportunity Institution authorized to provide research, educational information and other services only to individuals and institutions that function with non-discrimination with respect to race, creed, color, religion, age, disability, sex, sexual orientation, marital status, national origin, political opinions or affiliations. U.S. Department of Agriculture, Cooperative Extension Service, University of Florida, IFAS, Florida A. \& M. University Cooperative Extension Program, and Boards of County Commissioners Cooperating. Millie Ferrer, Interim Dean 
flow sensor for the product rate, a ground speed sensor, a rate controller, and actuator valves/motors. The GPS position coordinates are also needed for map-based VRT.

Pressure sensors are sometimes used in liquid applicators such as sprayers or liquid fertilizer applicators. These sensors provide an electrical signal that is proportional to the fluid or air pressure. Flow sensors are calibrated to measure volumetric, mass or even total flow in a pipe or chute. The design of these flow sensors can be propeller, ultrasonic/optical (for particle or slurry) or turbine/gear (for liquids). The ground speed can be measured from the rotational speed of a wheel or a gear on a shaft. Ground speed can also be measured with a Doppler radar sensor or a GPS receiver.

Application rate is adjusted by a variable rate controller, which is at the heart of the VRT system. VRT controllers incorporate microcontrollers or embedded computers that read sensor inputs, GIS prescription maps, and user commands and calculate the correct application rate through a formula or algorithm. The correct rate is then translated into actual product output through actuators, often via valves and solenoid or hydraulic motors and conveyors. Pulse Width Modulation (PWM) is a popular electronic method used by microcontrollers for signaling the actuators to deliver the exact rate. The rate formula either uses physical characteristics of the trees measured with the sensors and user settings to calculate the correct rates, or reads the rates directly from a GIS prescription map in the computer memory. Prescription maps are created from yield maps, soil maps, crop nutrient levels, aerial images or maps of soil electrical conductivity.

A range of variable rate controllers are available commercially and can interface with different devices through standard connectors. An important consideration when selecting a VRT control system is the response times of its various components, because a rapidly responding system is needed to make the quick rate changes while moving from tree to tree. The system also needs an automatic "look ahead" feature capable of providing the predictive speed compensation required to correctly synchronize product rates with the correct trees after subtracting inherent system lag times.

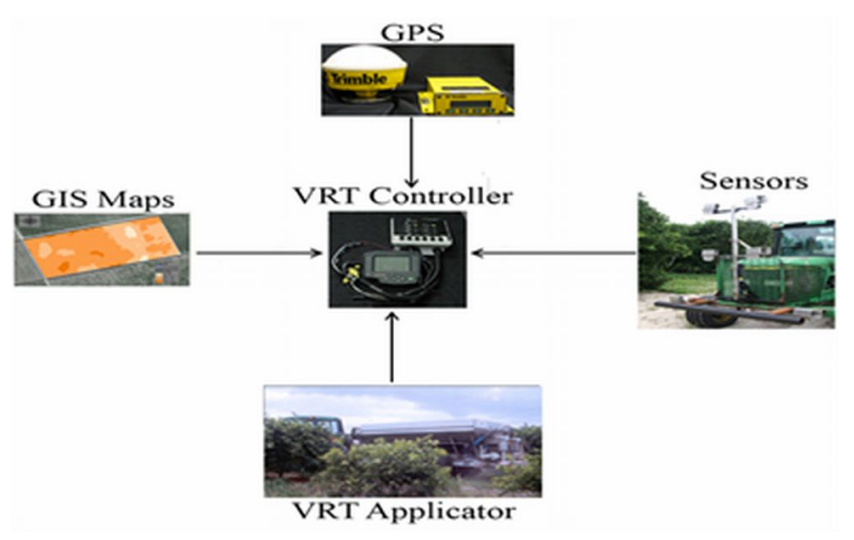

Figure 1. Main compontents of a typical VRT system

\section{Sensors for VRT in Citrus}

Sensors are essential components for on-the-go application of agrochemicals. A major advantage of sensors over prescription maps is that they provide up-to-date information at the time of the application. Prescription maps quickly become outdated, for example when diseased trees are removed or the grove sustains hurricane or freeze damage. For citrus VRT applications, the sensors are used to detect the tree and its size. Ultrasonic, photoelectric, and laser sensors manufactured by different companies were tested for VRT applications in citrus. Ultrasonic sensors can detect the presence of a target or measure the distance to the target by sending a pulsed ultrasound wave and then measuring the time for the reflection and return of the wave at the speed of sound. The canopy volume of the tree can be measured by calculating the distance of the tree canopy at several points. The photoelectric sensor uses a near-infrared LED light source directed toward the tree and the tree is detected by the reflection of the light back to the sensor. Laser sensors use a narrow scanning laser beam to detect a tree. The laser sensor scans the tree at many different points to measure the canopy volume. The information from the sensors is fed to the VRT controllers in real time to apply correct amounts of product. The lag time that on-the-go sensors create can be corrected in software applications using the "look ahead" feature.

\section{Variable Rate Spreaders}

Variable rate spreaders apply dry granular fertilizer, lime, biosolids, and some granular pesticides. Most commonly used applicators are either spinner spreaders or pneumatic spreaders. 
There may be more than one hopper to hold the desired products and separate drive units and metering devices for each hopper to determine the amount of each type of granular material to be applied. For citrus production, the most common configuration is the dual-chain spreader where independent left and right chains are fed from a single large hopper but are treated as two "products" for control purposes. The VRT controller should, therefore, have two channels for independent control of product rates to trees on the left and right of the spreader. The rate of fertilizer can be changed by adjusting the speed of a conveyor chain, height of a gate or rotation of an auger depending on the type of metering device. VRT fertilization has enhanced the performance of the Ridge Citrus Nitrogen-Best Management Practices (N-BMPs) in Florida, both economically and environmentally.

\section{Variable Rate Liquid Applications}

Variable rate liquid applicators in citrus groves are mainly air-blast pesticide sprayers or sometimes herbicide boom sprayers with liquid fertilizer which vary the application rates according to the size of the trees in the grove. Pesticide sprayers direct their spray nozzles in predetermined groups at different heights of the tree canopy. Therefore, the canopy sensors should be aimed to match the same canopy zones targeted by the nozzle groups. Common air-blast sprayers have three different spray zones on each side and, therefore, six separate canopy sensors. Liquid fertilizer should be dispensed according to the tree size (canopy height or volume) measured with on-the-go sensors. Proper synchronization of liquid VRT applications is also important and is achieved with an automated "look-ahead" feature. Variable rate chemical spraying is becoming popular and a number of VRT sprayers are available in Florida.

\section{Economics of VRT}

In principle, variable rate application of grove inputs can reduce the cost of production and also increase yields, both of which increase profits. In practice, increased yields from VRT in citrus groves are difficult to demonstrate and the main economic benefit is from reduced input costs, fuel, time, and labor savings. Similar results have been reported in studies with VRT on row crops. The reduction of production costs when changing to VRT is very significant and many citrus growers achieve equipment payback in one season. A study conducted by UF/IFAS found that a new VRT spreader would cost approximately $\$ 30,000$ to $\$ 40,000$ and a VRT conversion of an existing spreader would cost about $\$ 13,000$. For example, in 2005 a conservative 15\% reduction in fertilizer would save $\$ 52 /$ ha ( $\$ 21 / \mathrm{ac}$ ) and 1,380 acres of use would pay for the spreader. With current (2008) inflated fertilizer prices, a mere $10 \%$ fertilizer saving could save the Florida citrus industry $\$ 16$ million per year if all growers used VRT. In practice, there is an estimated average saving of 25 to $30 \%$ of agro-chemicals when applied with variable rate equipment, and a scientific study conducted by UF/IFAS in a cooperator grove recorded savings of $40 \%$ and significant reductions in nitrate leaching from the soil.

Sensor-based VRT systems for application of fertilizer in citrus orchards are commercially available. Also, existing fertilizer applicators can be equipped with VRT systems to do VRT application of fertilizers in orchards. Table-1 lists the name and contact information of some of the dealers that provide these equipment.

\section{References:}

Miller, W. M., A. W. Schumann, J. D. Whitney, and S. Buchanon. 2003. VRT citrus test plot applications of granular fertilizer. ASABE Paper No. 031127. St. Joseph, Mich.: ASABE.

Ping, J.L., R.B. Ferguson, and A. Dobermann. 2008. Site-specific nitrogen and plant density management in irrigated maize. Agron. J. 100:1193-1204.

Sevier, Brian J. and Won Suk Lee. 2005. Precision Farming Adoption in Florida Citrus: A Grower Case Study. ASABE Paper no.: 051054. St. Joseph, Mich.: ASABE

Schumann, A.W., W.M. Miller, H.K. Hostler, S. Buchanon, and S. Cugati. 2005. Nutrient Placement Using Variable Rate Technology (VRT). UF/IFAS Citrus Nutrient BMP Program. http://citrusbmp.ifas.ufl.edu/ 
Workshop\%20Presentations/

2005\%20BMP\%20meetings_Shumann.pdf

Schumann, A.W., H.K. Hostler, S.M. Buchanon, and Q. Zaman. 2006. Relating citrus canopy size and yield to precision fertilization. Proceedings of the Florida State Horticultural Society 119(2007). 9 pp.

Schumann, A.W., W.M. Miller, S.A. Cugati, H.K. Hostler and S.M. Buchanon. 2006. Optimizing variable rate granular fertilizer spreader performance for single-tree prescription zones. American Society of Agricultural and Biological Engineers Annual International Meeting, July 2006. Paper No. 061073. St. Joseph, Mich.: ASABE. 13 pp.

Schumann, A.W., W.M. Miller, Q.U. Zaman, K.H. Hostler, S. Buchanon, and S. Cugati. 2006. Variable rate granular fertilization of citrus groves: spreader performance with single-tree prescription zones. Applied Engineering in Agriculture 22(1): 19-24.

Tumbo S. D., M. Salyani, W. M. Miller, R. Sweeb, S. Buchanon. 2007. Evaluation of a Variable Rate Controller for Aldicarb Application around Buffer Zones in Citrus Groves. Computers and Electronics in Agriculture, Vol. 56(2):147-160.

Zaman, Q., A.W. Schumann, and S. Shibusawa. 2006. Impact of variable rate fertilization on nitrate leaching in a citrus orchard. 8th International Conference on Precision Agriculture, Minneapolis, Mn. 15 pp. 
Table 1. Some of the companies involved with VRT in Florida

\begin{tabular}{|c|c|c|}
\hline $\begin{array}{c}\text { Chemical Containers, Inc. } \\
\text { Kieth Hollingsworth, CCA } \\
\text { Post Office Box } 1307 \\
\text { Lake Wales, FL 33859-1307 } \\
\text { Tel: } 863-638-1407,800-346-7867 \\
\text { www.chemicalcontainers.com }\end{array}$ & $\begin{array}{l}\text { Tree-See Control Systems } \\
\text { Charles F. Roper } \\
120 \text { S. Dillard St. } \\
\text { Winter Garden, FL } 34787 \\
\text { Tel: } 1-800-872-5032 \\
\text { http://www.treesee.com }\end{array}$ & $\begin{array}{c}\text { Newton Crouch } \\
\text { Brian Crosby } \\
9545 \text { US Highway } 27 \text { S } \\
\text { Sebring, FL } 33876 \\
\text { Tel: } 863-655-0273\end{array}$ \\
\hline $\begin{array}{c}\text { Precision Ag Resources, Inc. } \\
\text { Mike Machek } \\
\text { Tel: 1-800-899-5502 } \\
\text { Cell: } 904-631-3086 \\
\text { http://www.pargps.com/ }\end{array}$ & $\begin{array}{c}\text { Midwest Technologies } \\
\text { P.O. Box } 7900 \\
\text { Wheaton, StatelL } 60189-7900 \\
\text { Tel: } 630-665-5000 \\
\text { Fax: } 630-665-5292 \\
\text { http://www.mid-tech.com }\end{array}$ & $\begin{array}{c}\text { Farmscan } \\
\text { 6 Sarich Way, Technology Park } \\
\text { BENTLEYWA } 6102 \\
\text { Australia } \\
\text { Tel:+61 } 894701177 \\
\text { Fax: +61 } 894702855 \\
\text { http://www.farmscan.net }\end{array}$ \\
\hline $\begin{array}{l}\text { M\&D Diamond Spreader } \\
\text { Desoto Machine, Inc } \\
2692 \text { NE Nat Ave } \\
\text { Arcadia, FL } 34266 \\
\text { Tel: } 863-494-0703 \\
\text { 800-494-0335 }\end{array}$ & $\begin{array}{c}\text { Durand Wayland } \\
\text { Rick Cordero } \\
\text { PO Box } 1404 \\
\text { Lagrange, GA } 30241-1404 \\
\text { Tel: } 1-800-241-2308 \\
\text { http://www.durand-wayland.com }\end{array}$ & $\begin{array}{l}\text { Dickey John Corporation } \\
5200 \text { DICKEY-john Road } \\
\text { Auburn, IL 62615 } \\
\text { Tel: } 217-438-337 \\
\text { www.dickey-john.com/ }\end{array}$ \\
\hline
\end{tabular}

